\title{
OPTIMASI EKSTRAKSI DAN PENENTUAN KANDUNGAN \\ KATEKIN DALAM TEH HIJAU (Camellia sinensis) MENGGUNAKAN METODA HPLC
}

\author{
Sudjatini $^{1}$
}

\begin{abstract}
This research was designed to determine the optimum period extraction time for catechin green tea using boiling water and ethyl acetate as a solubilizing agent, whereas the composition and the content of catechin green tea were measured using High Performance Liquid Chromatography (HPLC). A single factor experiment design was used. The period extraction time of green tea using boiling water and ethyl acetate were 5, 20, 35 and 60 minutes. The proportion of green tea at the extraction process was 1:15 (weight/volume). The extraction process using boiling water was done twice to get the maximum extracted catechin yield. The extracted catechin of green tea were, therefore, compared with epi-catechin as standard solution. The research's results show that the optimum period for extraction time of green tea using boiling water and ethyl acetate were 35 and 20 minutes, respectively. The extracted green tea using boiling water was $41.39 \%$ of its dry weight, and those extracted green tea contained catechin as high as $60.62-61.78 \%$. Catechin compound in green tea residues extracted using ethyl acetate was $5.31 \%$ from $58.35 \%$ the total green tea residues. The composition of catechin in the first boiling water extraction, the second boiling water extraction and pressure extraction consisted of epigallocatechin (EGC), epigallocatechin-gallat (EGCG), epicatechin (EC) and epicatechin-gallat (ECG). ECG was only found in green tea residue extracted using ethyl acetate. The total catechin compound in green tea extracted using boiling water and ethyl acetate was $27.73 \%$ of dry weight, consisted of EGC, EGCG, EC and ECG were $14.74,1.73,8,35$ and $2.91 \%$ of green tea dry weight, respectively
\end{abstract}

Keywords: green tea, catechin, polyphenol, freeze-dryer, HPLC.

\begin{abstract}
ABSTRAK
Penelitian ini bertujuan untuk mempelajari waktu ekstraksi senyawa katekin dalam teh hijau yang optimal dengan menggunakan pelarut air dan etil asetat dan evaluasi kandungan dan komposisi katekin dalam ekstrak teh hijau. Penelitian dilakukan dalam dua tahap, yaitu (1) Penentuan waktu ekstraksi teh hijau yang optimal menggunakan pelarut air dan etil-asetat; dan (2) Analisis senyawa katekin di dalam ekstrak teh hijau dengan HPLC (Hight Performance Liquid Chromatography). Penelitian dilakukan dengan faktor tunggal yaitu waktu ekstraksi teh hijau $(5 ; 20 ; 35$; dan 60 menit) dengan air mendidih $\left(100^{\circ} \mathrm{C}\right)$; dan dengan pelarut etil asetat. Ekstraksi teh hijau dengan air dan etil asetat dilakukan dengan perbandingan 1:15 (b/v) dan ekstraksi dengan air dilakukan dua kali agar katekin yang terekstrak maksimal. Hasil ekstraksi dianalisis menggunakan HPLC dengan senyawa standar epikatekin (EC). Hasil penelitian menunjukkan bahwa waktu ekstraksi teh hijau dengan pelarut air mendidih $\left(\mathrm{t} .100^{\circ} \mathrm{C}\right)$ yang optimal adalah 35 menit, sedangkan ekstraksi dengan etil asetat yang optimal adalah 20 menit. Dari hasil ekstraksi teh hijau ini diperoleh ekstrak teh yang larut air sebesar 41,39 \% bk dan ekstrak yang larut air ini mengandung katekin sebesar 60,62-61,78 \%. Senyawa katekin dalam ampas teh yang larut dalam etil asetat adalah sebesar 5,31\% dari 58, $35 \%$ ampas teh yang didapatkan. Komposisi katekin yang terdapat di dalam ekstrak air pertama (EA-1), ekstrak air kedua (EA-2) dan ekstrak pres (EP) terdiri dari epigalokatekin (EGC), epigalokatekin-galat (EGCG), epikatekin (EC), dan epikatekin-galat (ECG). Sedangkan dalam ampas, hanya terdapat epigalokatekin (EGC) yang larut dalam pelarut etil asetat. Total senyawa katekin utama yang diperoleh dari ekstraksi teh hijau menggunakan pelarut air dan etil asetat adalah 27,73\% berat kering teh hijau, dengan komposisi EGC: $14,74 \%$, EGCG: $1,73 \%$, EC: 8,35 \%, dan ECG: 2,91 \% berat kering teh hijau.
\end{abstract}

Kata kunci: Teh hijau, polifenol, katekin, freeze-dryer, HPLC.

\section{Pendahuluan}

Teh hijau merupakan salah satu sumber antioksidan alami yang dikonsumsi oleh masyarakat luas karena memiliki rasa yang enak dan memiliki khasiat menyegarkan tubuh. Hal ini disebabkan oleh kandungan senyawa aktif yaitu senyawa polifenol yang tinggi, terutama kelompok flavonoid yang terdiri dari flavanol (katekin, galokatekin, epikatekin, epikatekin galat,

\footnotetext{
${ }^{1}$ Program Studi Teknologi Pangan Fakultas Teknologi Pertanian Universitas Widya Mataram Yogyakarta

\sudjatini@gmail.com
} 
epigalokatekin, dan epigalokatekin galat); flavonol (quercetin, kaemferol, dan glikosidanya); flavone (vixetin dan iso vixetin); dan asam fenolik (asam galat dan asam klorogenat) (Hartoyo, 2003; Wang, et al., 1994).

Antioksidan mempunyai peran penting dalam mencegah perubahan yang terjadi dalam makanan yang mengandung lipid yang disebabkan oleh proses oksidasi. Senyawa lipid yang mengalami proses oksidasi akan membentuk hidroperoksida yang merupakan radikal bebas sebagai produk oksidasi primer, namun bersifat tidak stabil. Pada perkembangannya hidroperoksida berubah menjadi aldehid dan keton yang merupakan produk oksidasi skunder dan menyebabkan bahan pangan berlemak mempunyai bau tengik (rancid). Untuk mencegah terjadinya proses oksidasi pada bahan pangan berlemak, selama ini secara luas digunakan antioksidan sintetik, seperti butylated hydroxytoluene (BHT), butylated hydroxyanisole (BHA), atau TBHQ (Giese, 1996). Namun penggunaan antioksidan sintetik dalam jangka waktu yang lama dan dosis yang berlebihan dapat menyebabkan karsinogenik maupun kanker (Barlow, 1989). Untuk mengatasi hal ini, maka pemanfaatan antioksidan alami perlu ditingkatkan karena lebih aman bagi kesehatan.

Salah satu cara untuk mengekstraksi senyawa katekin dalam teh adalah dengan ekstraksi menggunakan pelarut. Menurut Stahl (1969), senyawa polifenol teh bersifat larut dalam air dan sebagian juga larut dalam etanol serta etil asetat. Chen et al., (1996) mengekstraksi teh hijau, teh hitam dan teh oolong dengan pelarut etanol; dan ternyata ekstrak etanol dari teh hijau memiliki aktivitas antioksidatif yang lebih efektif dalam menghambat proses oksidasi dibandingkan teh hitam dan teh oolong..

Suematsu et al. (1995) menyatakan bahwa ekstraksi katekin dan kafein teh dipengaruhi oleh suhu, waktu dan media ekstraksi. Sementara itu Price dan Spitzer (1993) telah menentukan empat penyusun utama flavonoid teh yang terdiri dari epikatekin (EC), epigallokatekin (EGC), epigallokatekin-gallat (EGCG), dan epikatekingallat (ECG).
Penelitian ini bertujuan untuk menentukan waktu ekstraksi teh hijau menggunakan air dan etil asetat yang optimal dan dimaksudkan untuk mendapatkan komponen flavonoid yang maksimal di dalamnya, terutama empat penyusun utama katekin teh hijau.

\section{Metode penelitian}

Teh hijau dengan kualitas Super peko diperoleh dari PT.Pagilaran Yogyakarta. Bahan kimia yang digunakan adalah etil asetat, asam asetat, metanol, dimetilformamid, aquades, aquabides dan epikatekin standar. Semuanya menggunakan grade khusus untuk analisis dengan alat HPLC dan uv-vis Spektrofotometer. Peralatan penelitian yang utama adalah rotary evaporator, freeze-dryer, 1 unit HPLC dengan uv-vis spektrofotometer sebagai detektor pada panjang gelombang $280 \mathrm{~nm}$ dan kolom C18-Bondapal (3,9 x $300 \mathrm{~mm}$ ), neraca analitik (Sartorius), spektrofotometer (Milton Roy, Spektronik 1201), penangas air, termometer, magnetik stirrer, hidroulik press, pendingin balik \& alat gelas.

Penelitian ini dibagi menjadi 2 tahap yaitu penentuan waktu ekstraksi teh hijau yang optimal menggunakan pelarut air dan etil asetat; dan analisis kandungan senyawa katekin di dalam ekstrak teh hijau dengan HPLC. Penentuan waktu optimal ekstraksi teh hijau dengan pelarut air dan etil asetat.

Sebelum ekstraksi teh hijau, dilakukan penentuan besarnya panjang gelombang dari warna seduhan teh hijau dengan pelarut air dan etil asetat, dengan cara scaning menggunakan uvvis spektrofotometer. Setelah diketahui panjang gelombang masing-masing seduhan, kemudian dilakukan penentuan waktu ekstraksi teh hijau dengan pelarut air dan etil asetat. Dengan melalui orientasi awal dapat diketahui pula perbandingan antara banyaknya sampel teh dengan volume pelarut yang digunakan.

Penentuan waktu ekstraksi teh dengan pelarut air mendidih dilakukan dengan variasi waktu adalah 5, 20, 35 dan 60 menit, dan ekstraksi dilakukan dua kali, sehingga diperoleh ekstrak teh larut air 1 (EA-1) dan ekstrak teh larut air 2 (EA2). Hasil ekstraksi dilakukan penyaringan dan filtratnya dianalisis absorbansinya dengan 
panjang gelombang hasil scaning. Ampas teh dari ekstraksi air, dipres dengan tekanan $200 \mathrm{~kg} / \mathrm{cm} 2$ selama 2 menit, dan hasil pengepresan dilakukan pengeringan beku. Ampas teh lalu dikeringkan dengan suhu $55^{\circ} \mathrm{C}$ selama 25 menit, dihaluskan untuk pengecilan ukuran dan kemudian diekstraksi dengan etil asetat dengan variasi waktu 10, 20, 35 dan 60 menit. Ekstrak dari ampas tersebut kemudian dianalisis absorbansinya dengan panjang gelombang hasil scaning. Semua data dianalisis statistik dan dilanjutkan dengan uji Dunkan. Tahap berikutnya adalah optimasi ekstraksi teh hijau dengan pelarut air dan etil asetat menggunakan waktu ekstraksi yang telah ditentukan sebelumnya.

Optimasi Ekstraksi Teh Hijau dengan Pelarut Air dan Etil asetat. Teh hijau $20 \mathrm{~g}$ ditambah dengan aquades $300 \mathrm{ml}(1: 15) \mathrm{b} / \mathrm{v}$, dididihkan selama 35 menit, lalu disaring untuk memisahkan ampas dengan filtratnya dan diperoleh filtrat-1 dan ampas-1. Ampas-1 diekstraksi satu kali lagi dengan metode yang sama dan setelah disaring didapatkan filtrat-2 dan ampas-2. Filtrat-1 dan filtrat-2 dikeringkan dengan freeze dryer selama 48 jam, diperoleh ekstrak air-1 (EA-1) dan ekstrak air-2 (EA-2). Ampas teh dipres untuk mengurangi air yang masih tertinggal dengan tekanan $200 \mathrm{~kg} / \mathrm{cm} 2$ selama 2 menit dan didapatkan ekstrak hasil pengepresan (EP) lalu dikeringkan dengan freeze dryer selama 48 jam. Ekstrak air tersebut ditimbang, dianalisis kadar airnya dan disimpan pada suhu $-4^{\circ} \mathrm{C}$.

Ampas teh setelah dipres dikeringkan pada suhu $55^{\circ} \mathrm{C}$ selama 25 menit, kemudian dihaluskan dan ditimbang. Ampas halus lalu diekstraksi dengan pelarut etil asetat dengan perbandingan teh:solven=1:15 (b/v). Ekstraksi dilakukan dalam erlenmeyer tertutup dan menggunakan magnetic stirrer selama 20 menit. Campuran disaring dan filtratnya dipekatkan dengan rotary evaporator, tekanan vakum 20 in $\mathrm{Hg}$ dan suhu $50^{\circ} \mathrm{C}$ selama 20 menit. Ekstrak dari ampas yang larut etil asetat (EEAs) kemudian ditentukan kadar bahan padat terlarutnya lalu disimpan pada suhu $-4^{\circ} \mathrm{C}$.

Analisis kandungan katekin
Dari hasil ekstraksi teh hijau dengan pelarut air yaitu EA-1, EA-2, dan EP; serta ekstrak ampas dengan pelarut etil asetat (EEAs) kemudian ditentukan komponen katekinnya dengan metode HPLC (Price dan Spitzer, 1993). Hasil kromatogram ekstrak teh dibandingkan dengan waktu retensi EC standar dan senyawa EC, EGC, EGCG dan ECG ditentukan dengan metode Lin et al. (1996).

Analisis Data

Ekstraksi teh hijau dengan pelarut air dan etil asetat dan analisis katekin teh dilakukan dengan 3 kali ulangan. Data yang diperoleh kemudian dianalisis secara statistik dengan metode ANOVA pada level signifikansi 5\% dan dilanjutkan dengan uji Duncan's (Gomez and Gomez, 1984).

\section{Hasil dan pembahasan}

Hasil analisis kadar air teh hijau pada penelitian ini adalah sebesar $6,96 \%$, dan dari penelitian ini dapat diperoleh beberapa hasil sebagai berikut:

\section{Scaning untuk penentuan panjang gelombang}

Hasil scaning warna seduhan teh hijau menggunakan uv-vis spektrofotometer menunjukkan bahwa panjang gelombang seduhan teh yang menggunakan pelarut air suling (aquades) adalah $380 \mathrm{~nm}$, sedangkan panjang gelombang seduhan teh hijau dengan pelarut etil asetat adalah 411,5 nm. Dari scaning tersebut ternyata banyak puncak yang muncul yang masing-masing menunjukkan panjang gelombang yang berlainan (Gambar tidak disajikan). Hal ini disebabkan oleh adanya senyawa yang terlarut dan ikut menyusun warna seduhan teh, seperti gula, asam-asam amino, dan lain-lain (Harler, 1979). Hasil scaning yang diambil adalah hasil yang menentukan panjang gelombang dari penyusun warna paling dominan ditunjukkan oleh luas areal puncak paling besar.

\section{Penentuan waktu ekstraksi Teh hijau}

Hasil penentuan waktu ekstraksi teh hijau dengan pelarut air suling ditunjukkan dari hasil analisis statistik menggunakan anova dan 
dilanjutkan dengan uji Duncan's untuk menentukan tingkat perbedaan masing-masing perlakuan (Tabel 1). Sedangkan hasil penentuan waktu ekstraksi teh hijau menggunakan pelarut etil asetat ditunjukkan pada Tabel 2.

Tabel 1. Nilai absorbansi seduhan teh hijau dengan pelarut air suling pada berbagai waktu ekstraksi.

\begin{tabular}{cc}
\hline $\begin{array}{c}\text { Lama ekstraksi } \\
\text { (menit) }\end{array}$ & Absorbansi \\
\hline 5 & $1,690 \mathrm{a}$ \\
20 & $1,538 \mathrm{~b}$ \\
35 & $1,356 \mathrm{c}$ \\
60 & $1,280 \mathrm{c}$ \\
\hline
\end{tabular}

Keterangan: Notasi yang sama menunjukkan bahwa antara perlakuan tidak berbeda nyata pada taraf signifikan $5 \%$.

Tabel 2. Nilai absorbansi seduhan teh hijau dengan pelarut etil asetat pada berbagai waktu ekstraksi.

\begin{tabular}{cc}
\hline $\begin{array}{c}\text { Lama ekstraksi } \\
\text { (menit) }\end{array}$ & Absorbansi \\
\hline 10 & $1,614 \mathrm{a}$ \\
20 & $1,350 \mathrm{~b}$ \\
35 & $1,136 \mathrm{bc}$ \\
60 & $0,936 \mathrm{c}$ \\
\hline
\end{tabular}

Keterangan: Notasi yang sama menunjukkan bahwa antara perlakuan tidak berbeda nyata pada taraf signifikan $5 \%$.

Hasil analisis dari waktu ekstraksi teh hijau dengan pelarut air suling menunjukkan bahwa lama waktu ekstraksi teh berpengaruh sangat nyata terhadap warna seduhan teh. Semakin lama waktu ekstraksi teh hijau dengan pelarut air, makin banyak senyawa penyusun teh, terutama katekin teh yang terlarut di dalamnya yang berakibat perbedaan nilai absorbansinya. Dari Tabel 1 diketahui bahwa antara perlakuan menunjukkan hasil yang berbeda nyata pada lama ekstraksi 5, 20, dan 35 menit. Namun absorbansi pada lama ekstraksi 35 menit tidak berbeda nyata dengan 60 menit. Jadi banyaknya senyawa katekin yang terlarut dalam seduhan teh hijau pada lama ekstraksi 35 menit adalah sama dengan banyaknya senyawa katekin yang terlarut dalam seduhan teh hijau pada lama ekstraksi 60 menit. Dengan demikian, waktu yang paling efektif untuk ekstraksi katekin teh hijau dengan pelarut air adalah 35 menit.

Hasil analisis dari waktu ekstraksi teh hijau dengan pelarut etil asetat pada Tabel 2 menunjukkan bahwa lama waktu ekstraksi teh berpengaruh sangat nyata terhadap warna seduhan teh. Semakin lama waktu ekstraksi teh hijau dengan pelarut etil asetat, makin banyak senyawa penyusun teh terutama katekin teh yang terlarut di dalamnya yang berakibat perbedaan nilai absorbansinya.

Dari Tabel 2 diketahui bahwa antara perlakuan menunjukkan hasil yang berbeda nyata pada lama ekstraksi 10 dan 20 menit. Namun absorbansi pada lama ekstraksi 20 menit tidak berbeda nyata dengan 35 menit dan berbeda nyata dengan lama ekstraksi 60 menit. Dan absorbansi pada lama ekstraksi 35 menit tidak berbeda nyata dengan lama ekstraksi 60 menit. Jadi banyaknya senyawa katekin yang terlarut dalam seduhan teh hijau pada lama ekstraksi 20 menit adalah sama dengan banyaknya senyawa katekin yang terlarut dalam seduhan teh hijau pada lama ekstraksi 35 menit, namun tidak sama dengan ekstraksi 60 menit. Dengan demikian, waktu yang paling efektif untuk ekstraksi katekin teh hijau dengan pelarut etil asetat adalah 20 menit.

\section{Optimasi ekstraksi teh hijau dengan pelarut air dan etil asetat}

Ekstraksi katekin teh hijau dengan pelarut air suling dilakukan dengan lama waktu 35 menit, dan diulang dua kali, sehingga didapatkan ekstrak air-1 (EA-1) dan ekstrak air-2 (EA-2). Hasil pengepresan ampas teh didapatkan cairan warna hijau gelap disebut ekstrak pres (EP). Ampas teh setelah dipres, dikeringkan, dihaluskan dan diekstraksi dengan pelarut etil asetat dengan lama waktu ekstraksi 20 menit dan didapatkan ekstrak katekin dari ampas teh yang larut etil asetat (EEAp). Hasil ekstraksi katekin teh hijau dengan pelarut air disajikan pada Tabel 3. 
Tabel 3. Hasil ekstraksi katekin teh hijau dengan menggunakan pelarut air.

\begin{tabular}{lc}
\hline \multicolumn{1}{c}{ Hasil ekstraksi } & Prosentase (\%) \\
\hline Ekstrak Air-1 & $29,80 \pm 0,98$ \\
Ekstrak Air-2 & $9,00 \pm 0,74$ \\
Ekstrak Pres & $2,59 \pm 0,46$ \\
Ampas halus & $58,35 \pm 2,74$ \\
\hline
\end{tabular}

Hasil penelitian menunjukkan bahwa ekstrak teh yang terlarut dalam pelarut air suling mencapai $41,39 \%$ dari berat kering teh hijau. Sisanya adalah ampas halus, sebesar 58,35\% (Tabel 3). Ampas tersebut setelah dikeringkan dan dihaluskan kemudian diekstraksi dengan pelarut etil asetat selama 20 menit dan dihasilkan ekstrak yang larut etil asetat. Semua ekstrak kemudian ditentukan kandungan katekinnya.

\section{Hasil analisis senyawa katekin ekstrak teh hijau}

Hasil analisis senyawa katekin teh hijau dengan pelarut air suling terdiri atas ekstrak air-1 (EA-1), ekstrak air-2 (EA-2), dan ekstrak hasil pengepresan (EP); dan ekstrak katekin dari ampas dengan pelarut etil asetat (EEAs), dibandingkan dengan senyawa standar epikatekin (EC) dapat dilihat pada kromatogram (Gambar 3). Waktu retensi yang ditunjukkan oleh puncak dari senyawa standar epikatekin (EC) adalah pada menit ke 8,6 (Gambar 3 B).

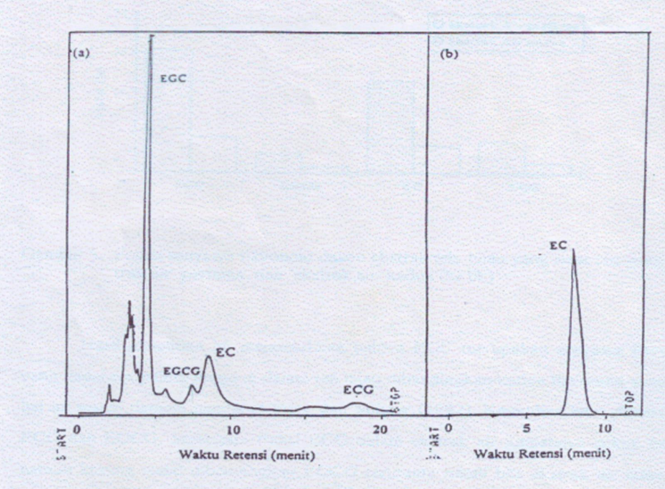

Gambar 3. Kromatogram hasil analisis katekin teh hijau dengan HPLC: (A). Senyawa ka tekin dalam ekstrak teh hijau; (B). Senyawa epikatekin standar (EC)
Berdasarkan pada tingkat polaritasnya (Lin, et al., 1996), empat katekin utama dalam teh hijau yaitu epigalokatekin (EGC), epigalokatekingalat (EGCG), epikatekin (EC), dan epikatekingalat (ECG) berturut-turut muncul pada menit ke 4,6 (EGC), ke 7,8 (EGCG), ke 8,6 (EC), dan ke 18,89 (ECG) (Gambar 3A). Dengan diketahui posisi masing-masing katekin, dapat ditentukan kandungan katekin pada ekstrak teh. Komposisi dan banyaknya katekin pada masing-masing ekstrak teh hijau dengan pelarut air dan etil asetat dapat dilihat pada Gambar 4 dan Tabel 4.

Tabel 4. Kadar dan komposisi flavonoid (katekin) dalam ekstrak teh hijau dan teh hijau

\begin{tabular}{|c|c|c|c|c|c|}
\hline \multirow{2}{*}{$\begin{array}{c}\text { Ekstrak } \\
\text { Teh } \\
\text { Hijau }\end{array}$} & \multicolumn{4}{|c|}{ Komposisi Flavonoid (\% bk) } & \multirow{2}{*}{$\begin{array}{c}\text { Kadar } \\
\text { Flavonoid } \\
\text { Teh Hijau } \\
(\% \text { bk }) \\
\end{array}$} \\
\hline & EGC & EGCG & $\mathrm{EC}$ & $\mathrm{ECG}^{\prime}$ & \\
\hline Ekstrak & & & & & \\
\hline $\begin{array}{c}\text { Air } \\
\text { Pertama } \\
(\text { EA-1) }\end{array}$ & 8,53 & 1,29 & 6,41 & 2,19 & $\begin{array}{c}18,42 \pm \\
0,97\end{array}$ \\
\hline Ekstrak & & & & & \\
\hline $\begin{array}{c}\text { Air } \\
\text { Kedua } \\
\text { (EA-2) }\end{array}$ & 2,44 & 0,39 & 1,9 & 0,72 & $\begin{array}{l}5,45 \pm \\
0,42\end{array}$ \\
\hline $\begin{array}{c}\text { Ekstrak } \\
\text { Pres } \\
\text { (EP) }\end{array}$ & 0,39 & 0,05 & 0,04 & 0 & $\begin{array}{l}0,48 \pm \\
0,03\end{array}$ \\
\hline $\begin{array}{l}\text { Ekstrak } \\
\text { Ampas } \\
\text { (EEAp) }\end{array}$ & 3,38 & 0 & 0 & 0 & $\begin{array}{c}3,38 \pm \\
0,21\end{array}$ \\
\hline Total & 14,74 & 1,73 & 8,35 & 2,91 & 27,73 \\
\hline
\end{tabular}

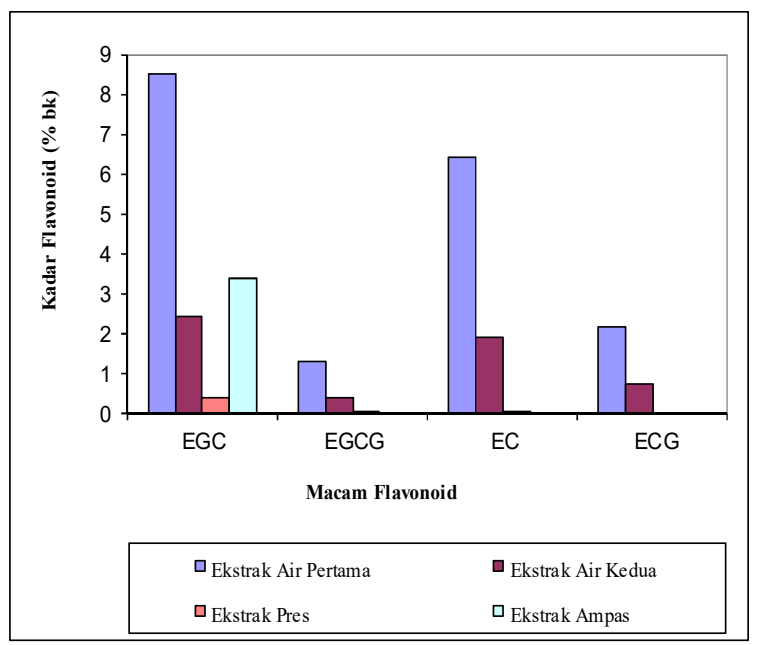

Gambar 4. Kadar dan komposisi flavonoid/katekin dalam ekstrak teh hijau yang larut air, yaitu ekstrak air pertama (EA-1), ekstrak air kedua (EA-2), dan ekstrak hasil pres (EP); serta katekin ampas teh yang larut etil asetat (EEAp). 
Gambar 4 menunjukkan bahwa dalam EA-1 mengandung senyawa katekin yang paling lengkap komposisi katekinnya yaitu EGC, EGCG, EC dan ECG; dan jumlahnya adalah 18,42 \%. EA2 juga mengandung katekin yang komposisinya masih lengkap, namun jumlahnya lebih rendah, yaitu 5,45 \%. Ekstrak hasil pengepresan (EP) juga mengandung EGC, EGCG dan EC meskipun jumlahnya sangat rendah. Sedangkan ekstrak etil asetat dari ampas hanya mengandung satu macam katekin, yaitu EGC.

Tabel 5. Kadar flavonoid (katekin) dalam ekstrak teh hijau dan teh hijau

\begin{tabular}{ccc}
\hline \multirow{2}{*}{ Ekstrak Teh Hijau } & \multicolumn{2}{c}{ Kadar Katekin $(\% \mathrm{db})$} \\
\cline { 2 - 3 } & $\begin{array}{c}\text { Ekstrak Teh } \\
\text { Hijau }\end{array}$ & Teh Hijau \\
\hline Ekstrak Air Pertama & $61,78 \pm 3,27$ & $18,42 \pm 0,97$ \\
Ekstrak Air Kedua & $60,62 \pm 4,64$ & $5,45 \pm 0,42$ \\
Ekstrak Pres & $18,40 \pm 0,87$ & $0,47 \pm 0,03$ \\
Ekstrak Etil Asetat & $5,31 \pm 0,33$ & $3,38 \pm 0,21$ \\
Ampas teh & & \\
Kadar katekin teh & & 27,73 \\
hijau (\% db) & & \\
\hline
\end{tabular}

Total katekin yang dapat diperoleh dari ekstraksi teh hijau menggunakan pelarut air dan etil asetat dalam penelitian ini mencapai 27,73\% berat kering teh hijau (Tabel 4 dan Tabel 5). Hal ini merupakan hasil optimasi ekstraksi yang cukup baik, mengingat bahwa tidak semua senyawa katekin dilakukan analisis, tetapi hanya empat penyusun katekin yang utama, yaitu epikatekin, epigalokatekin, epigalokatekin-galat dan epikatekin-galat. Hasil penelitian Price dan Spitzer (1992) menyatakan bahwa kadar flavanol teh hijau antara 15-30\% berat kering teh yang terdiri dari epigalokatekin (EGC), epigalokatekingalat (EGCG), epikatekin (EC) dan epikatekingalat (ECG). Sedang menurut Harler ((1979), jumlah katekin dalam teh hijau adalah sebesar 30 $\%$ berat kering teh.

\section{Kesimpulan}

Berdasarkan hasil penelitian ini dapat disimpulkan bahwa waktu ekstraksi teh hijau menggunakan pelarut air (t. $100^{\circ} \mathrm{C}$ ) yang paling optimal adalah 35 menit, sedangkan ekstraksi ampas teh hijau menggunakan pelarut etil asetat yang paling optimal adalah 20 menit. Banyaknya ekstrak teh yang larut dalam pelarut air adalah $41,39 \%$ dan ekstrak air ini mengandung katekin sebesar 60,62-61,78 \%. Sedangkan senyawa katekin dalam ampas teh yang larut dalam etil asetat adalah sebesar 5,31\% dari 58, 35\% ampas teh yang didapatkan. Komposisi katekin yang terdapat di dalam ekstrak air pertama (EA-1) dan ekstrak air kedua (EA-2) dan ekstrak pres (EP) terdiri dari epigalokatekin (EGC), epigalokatekingalat (EGCG), epikatekin (EC), dan epikatekingalat (ECG). Sedangkan dalam ampas, hanya terdapat epigalokatekin (EGC) yang larut dalam pelarut etil asetat. Total senyawa katekin utama yang diperoleh dari ekstraksi teh hijau menggunakan pelarut air dan etil asetat ini adalah $27,73 \%$ berat kering teh hijau, dengan komposisi EGC: $14,74 \%$, EGCG: 1,73 \%, EC: $8,35 \%$, dan ECG: $2,91 \%$ berat kering teh hijau.

\section{Daftar pustaka}

Barlow, S.M. 1989. Toxicological aspect of antioksidant used as food additives. Elsevier Applied Science, London.

Chen,ZY, PT. Chan, HM. Ma, KP. Fung and J. Wang. 1996. Antioksidative effect of ethanol tea extract on oxidation of canola oil. JAOCS, 73 (3):375-380.

Gomez, KA. and AA. Gomez. 1984. Statistical procedure for agricultural research. John Wiley and Sons, New York.

Harler, CR. 1979. Tea manufacture. Oxford Univ. Press, New York.

Hartoyo, A. 2003. Teh dan khasiatnya bagi kesehatan: Sebuah tinjauan ilmiah. Penerbit Kanisius. Yogyakarta.

Lin, YL., IM. Juan., YL. Chen, YC. Liang and JK. Lin. 1996. Composition of poliphenols in fresh tea leaves and associations of their oxygen-radical absorbing capacity with antiproliferative actions in fibroblast cells. J. Agric.Food Chem. 44, 1387-1394.

Price, WE and JC. Spitzer. 1992. Variations in tea amounts of individual flavanols in range of green teas. J. Food Chem. 42: 271-276.

Price, WE and JC. Spitzer. 1993. The temperature dependence of the rate of extraction of 
soluble constituents of black tea. J. Food Chem. 46: 133-136.

Stahl. 1969. The chemistry of tea and soluble tea and soluble tea manufacturing. Mc. Cormick and Co., Inc. Baltimore, Maryland.

Sudarmadji, S., B. Haryono dan Suhardi. 1984. Prosedur analisa untuk bahan makanan dan pertanian. Penerbit Liberty, Yogyakarta.

Suematzu, S., Y. Hisanobu, H. Saigo, R. Matsuda, and Y. Komatsu. 1995. A new extraction procedure for determination of caffeine and catechins in green tea (Studies on preservation of constituents in canned drinks). J. Food Sci and Technol. 42(6): 419-424. 